\title{
A VIRTUAL CLASSROOM FOR ARCHITECTURAL COMPOSITION SUBJECT: A REFLECTION ABOUT OPPORTUNITIES AND LIMITS
}

\author{
V. Cristini, L. García, Y. Hernández, J.L. Baró, M. Diodato, F. Vegas \\ Universitat Politécnica de Valéncia (SPAIN)
}

\begin{abstract}
This text aims to reflect on the proposal for the implementation of a virtual classroom for teaching the subject of architectural composition within the framework of Degree in Foundations of Architecture of the Higher Technical School of Architecture (ETSA) of the Universitat Politècnica de València, following the health emergency caused by the Sars Cov 19 virus in spring 2020.

Against this backdrop a summary is proposed of the adaptation and progressive fine-tuning of the subject taking into consideration different protocols and mechanisms characteristic of remote teaching. This constitutes a veritable metamorphosis in a time of major crisis, requiring a drastic shift from the classroom teaching system which has been in place for decades at ETSA. In this context the text describes the methodological guidelines developed to create the virtual classroom for the subject as well as the tools used to meet a series of objectives for teaching and learning digitally, specifically geared towards critical thinking among students. The text reflects on the distance learning model, known for its agility and difficulties.
\end{abstract}

This adaptation brings with it a series of limitations as well as a host of pedagogic opportunities and resources to be used innovatively. As teachers have come to understand, face-to-face and online teaching overlap to some extent.

It is true that after several months of use major points of convergence and divergence have been identified and taken into consideration when drawing up this initial assessment and retrospective of this teaching experience.

Keywords: Distance learning, e-content, theorical architecture subject, critical thinking.

\section{INTRODUCTION: THE SUBJECT OF ARCHITECTURAL COMPOSITION}

Spanish schools of architecture have always expressed an interest in typological and morphological research, lessons which are crucial to guaranteeing a preparatory approach to design, both theoretical and conceptual, among students, an approach encouraged in the workshops and laboratories for Projects and Urbanism. In this framework, Architectural Composition is a compulsory subject of 4.5 ECTS, which has been taught for several decades in the fourth year of the Degree in Foundations of Architecture of the School of Architecture of the Universitat Politècnica de València (Spain).

The aim of the subject of Architectural Composition is to provide students with an introduction to critical thinking and to weighing up the mechanisms for composition, linked to several crossdisciplinary stages of History of Architecture, thus developing their analytical, theoretical and reflective capacity both to express opinions and to make their own decisions when drawing up designs [9]. Therefore, in theoretical and practical classes students become involved in the study of the extensive and complex composition process, analysing formal, graphic and architectural aspects as well as basic theory and the authors who established certain lines of critical thinking.

\section{ARCHITECTURAL COMPOSITION AN CRITICAL THINKING}

Having been examining these precepts since the 2019 academic year, Architectural Composition is one of the subjects included in the Project for Educational Innovation and Improvement "ARQUITECTURA CRIITICA. Development of a methodology to work Critical Thinking in architecture students" promoted by the Institute of Education Sciences of the Universitat Politècnica de València (1653B/2019 coordinated by Prof. C. Mileto). The main aim of the project is to promote different learning actions to structure a work methodology for the cross-disciplinary skill of critical thinking among students of different levels, and also to improve their own perception of this skill. In this framework, the main basic objectives of the project have been to stimulate critical thinking among 
students, designing specific activities linked to the syllabus, developed mostly in groups and reinforced by the effective oral and written communication of results [5].

\subsection{The background the $2019 / 2020$ academic year: teaching in lockdown}

Throughout 2020 hundreds of reports and reflections on the parameters and casuistics of distance learning have been published in numerous media outlets and forums. This teaching system has become internationally widespread as an obligatory and necessary measure due to the lockdowns and restrictions following the Sars Cov19 virus pandemic [4]. Far from offering apocalyptic or hopeful scenarios [8] this text aims to provide an objective examination of a series of aspects, both positive and negative, which have affected the subject of architectural composition. For the first time ever, over $3 / 4$ of the subject classes have been affected by the limitations of in-person lessons and have been taught online (both synchronously and asynchronously) during the entire spring of 2020.

Within this framework the aim of this text is to examine the methodological approach used, detailing the platforms or technical means used. It also aims to propose an initial assessment which can be used to fine-tune remote teaching of this subject in the coming academic years or in any circumstances which may require it.

\section{THE VIRTUAL CLASSROOM OF ARCHITECTURAL COMPOSITION}

Although the shift from in-person Architectural Composition to the remote learning version was abrupt, online teaching is not new. Many universities have been applying data transmission strategies and teaching online classes for years, either in distance learning courses or through open access online education platforms. These Massive Online Open Courses or MOOCs have existed for decades [7]. The resources which these virtual academic offers usually include are basically recorded videconferences, consultation of a selection of material online, definition of self-assessment or group tasks, reviews and discussion forums. This is a wealth of resources and tools patiently structured and designed in a specifically virtual friendly setting (Moodle and MoodleCloud). The difference between these online teaching experiences and the one presented here is that the former were specifically designed to be completed remotely. However, the need to adapt in-person teaching to online teaching required updates in teaching methodologies, contents and virtual resources available, but lacked a suitable infrastructure and setting [1].

\subsection{Methodological adaptation}

Half the credits for the subject of Architectural Composition are taught as theory, while the other half is linked to the completion of several critical practices. The theoretical aspect consists in teaching comprehensive content, with participatory master classes relating to an entire series of composition matrices. Following a brief overview of the history of the subject, students are asked to detail parameters such as trajectory, place, light, material, form, space, structure, geometry and sustainability. In the practical exercises, students in groups of $3 / 4$ produce reports analysing 21 stcentury buildings matching these parameters, taking part in classroom debates which are closely followed by the teachers. Continuous assessment is implemented, with two written tests on the theory of the subject and three different submissions for presenting the reports.

\subsection{The limitations: feedback and interaction}

In general, online teaching has been subject to a series of major conditioning factors, not only logistic and technological for teachers and students (including the problem of infrastructures available to develop teaching), but also personal factors such as different family situations, problems striking a work-life balance, cases of COVID transmission and limited spaces in the home where teaching actions can be carried out [6]. After overcoming the shortcomings and inexperience in the use of unified communication and collaboration platforms (such as Teams, Webex and Zoom) a series of questions have arisen relating to effective communication by teachers in the classroom and active critical feedback from students, both in theoretical blocks and in practice.

No changes have been observed in the theoretical context of the subject and all the teaching units planned have been completed. However, the way they are taught has changed. Some teachers have taught synchronous theory classes while circumstances have forced others to upload files and recordings to the platforms and make use of forums and chats. In both cases the degree of interaction has been a weak point in adapting the methodology, possibly more so in the recordings. Screens are 
not classrooms and no matter how much a teacher tries to stimulate and encourage students the replies they receive and the productive atmosphere of the offline class in general is affected [3].

\subsection{The opportunities: online resources and critical analysis}

No changes have been observed in the practical content of the subject either and it was possible to carry out the planned actions (dossiers and debates). As in the case of the theory the way in which this is developed (virtual groups) and submission format (all in pdf) have also been modified. Although it is true that the degree of interaction with teachers has been affected, one positive aspect can be observed. More online resources have been made available to students during lockdown compared to previous years. In previous academic years teachers have insisted on catalysing the consultation of high quality digital resources [2] resorting to a wide range of sources. However, lockdown has led to journals, websites, platforms, documentaries, videos, interviews, libraries, etc... improving and promoting their digital visibility. Many publishers and/or bodies have made these accessible during lockdown, both in Spain and abroad. The enforced obligation to spend more time at home has served as encouragement for researching critical sources and more specific resources and a considerable increase in the desire for research compared to other academic years has been observed, as shown by the practical assessments, with marks out of 10 improving by 1.0/1.5 points (Fig.1).
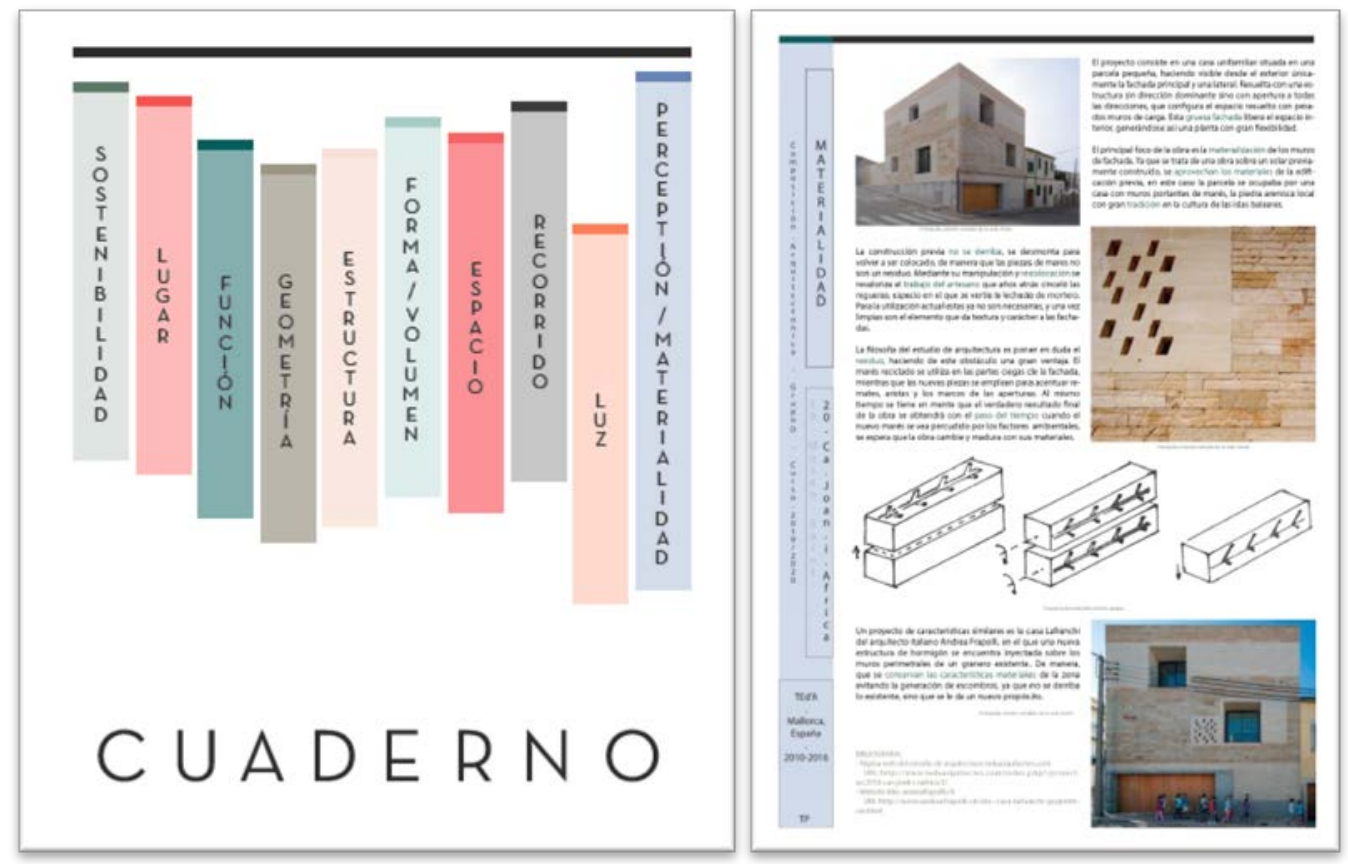

Figure 1. Delivery of online practical activity example. Students' credits: Casamayor, Piersanti, Ponzo, Quintero 2020

\subsection{The challenge: objective assessment}

A frankly complex stage observed in the Architectural Composition class was that relating to assessment tasks. Assessing practical exercises and debates was not complex as real time/prerecorded and individual/group monitoring was made possible by the communication platforms (Fig.2). In addition, as stated above, the results of the students in these cases have been extremely satisfactory. The most problematic aspect has been drawing up written tests, holding them online and the subsequent objective assessment.

With tests carried out virtually or telematically it was obviously possible to consult notes, teaching materials or access internet. For this reason the teachers put together a host of questions with limited time, monitoring the IDs of the computer devices and using specific anti-plagiarism software. In order to also carry out an objective assessment a whole series of open questions and interpretations were put together, leading to a degree of reasoning and a cross-disciplinary approach, rather than mnemonic or mechanical solutions. Some quiz tests (multiple choice, dichotomic, crossed...) were also used, attempting to make these as subtle as possible so that the alternatives and combinations of the answers were not obvious, but required an effective proven command of the subject matter. 

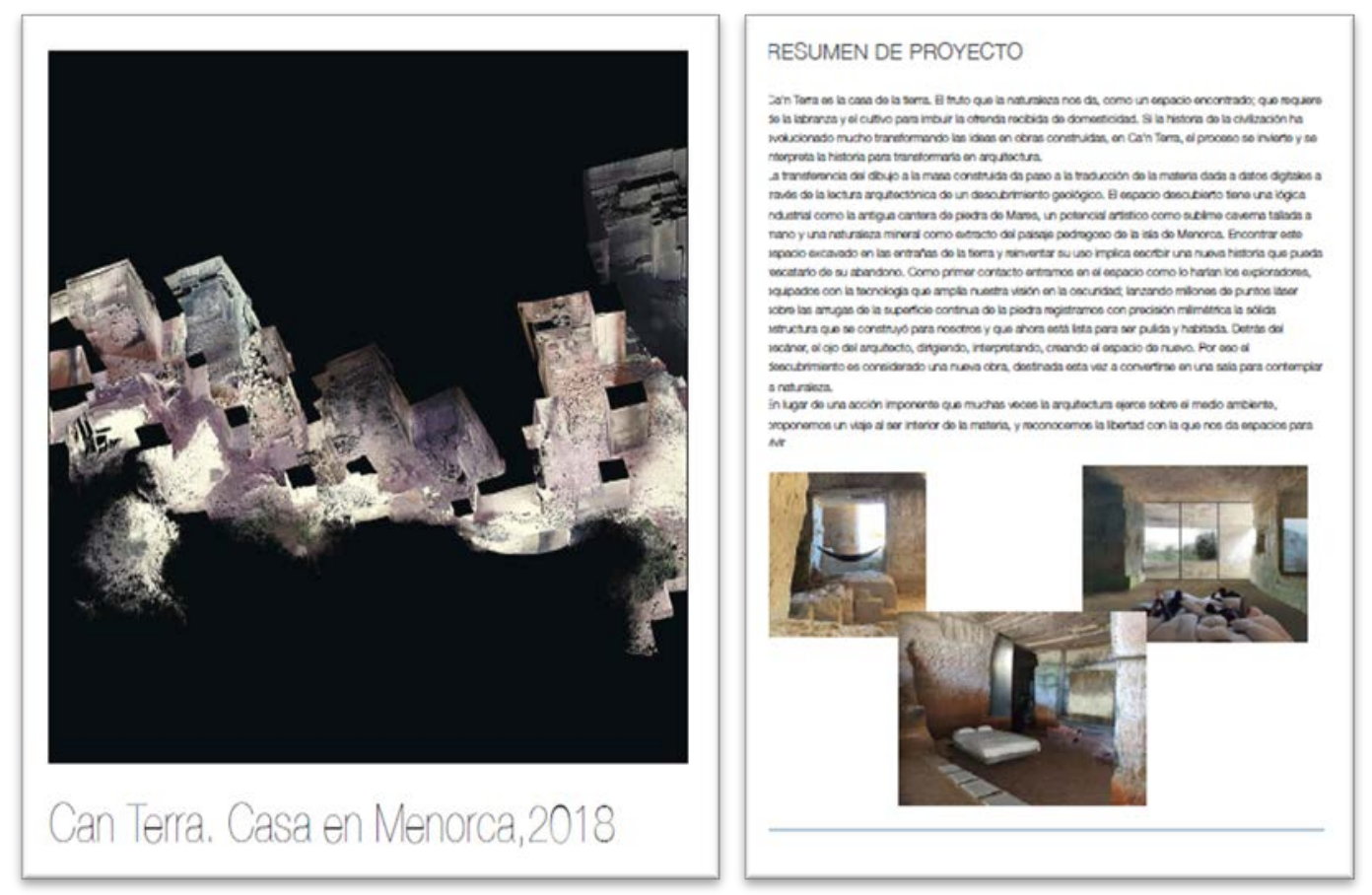

Figure 2 Example of practical online activity concerning a sustainability case study; credits: $A$. L. Vegas 2020

\section{CONCLUSIONS}

The subject of Architectural Composition, with a decidedly historical and theoretical component, as stated in the project "ARQUITECTURA CRÍTICA. Development of a methodology to work Critical Thinking in architecture students" is a subject which aims to develop and stimulate skills linked to critical thinking. In this context there is no doubt that the degree of interaction between students and teachers has become more rigid and has in part "cooled down" in online classes. At the same time, it is also true that the development of practical exercises and written tests have forced students to improve their capacity for analysis, both in the search for the necessary online resources and in the development of improved practices of written composition, reading and reflection. Compulsory lockdown and the subsequent $360^{\circ}$ change in the subject have been especially positive, despite objective difficulties and limitations. This is reflected in the shift in teachers' stances on teaching. Finally, the teaching process has been streamlined and the "learning to learn" option was chosen, ensuring that students can attain intellectual independence, especially in view of the circumstances. This was made possible by a special insistence on helping to develop more advanced skills such as critical thinking, implementing cognitive, meta-cognitive and general dispositional skills among students.

\section{ACKNOWLEDGEMENTS}

This text is part of the Project for Educational Innovation and Improvement "ARQUITECTURA CRÍTICA. Desarrollo de una metodología para trabajar la competencia transversal de "Pensamiento crítico" en estudiantes de arquitectura", main researcher: C. Mileto, funded by the Institute of Education Sciences of the Universitat Politècnica de València.

\section{REFERENCES}

[1] CABRERA I FAUSTO, I., FENOLLOSA E. (2020) "La docencia de la arquitectura durante el confinamiento. El caso de la Escuela de Valencia" in JIDA'20. VIII Jornadas sobre Innovación Docente en Arquitectura Málaga, eAM'-UMA Ed., p. 1074-1084. https://upcommons.upc.edu/bitstream/handle/2117/331367/9470-10587-1PB.pdf?sequence=1\&isAllowed=y (Consult January 2021) 
[2] CRISTINI, V. ET AL. (2013), "References organization as a digital educational resource" in 7th International Technology, Education and Development Conference, 4-5 March, 2013, lated Ed., p. 1055-1062, https://library.iated.org/view/CRISTINI2013REF(Consult January 2021)

[3] CORNADÓ C., CRESPO E., MARTIN E. (2020), "Asignaturas tecnológicas en Arquitectura en el Confinamiento: hacia una enseñanza aplicada", in JIDA'20. VIII Jornadas sobre Innovación Docente en Arquitectura Málaga, eAM'-UMA Ed., p.175-185. https://revistes.upc.edu/index.php/JIDA/article/view/9335 (Consult January 2021)

[4] ESPAÑA. REAL DECRETO 463/2020, de 14 de marzo, por el que se declara el estado de alarma para la gestión de la situación de crisis sanitaria ocasionada por el COVID-19. BOE, 14 de marzo de 2020, núm. 67, p. 25390-25400. https://www.boe.es/diario_boe/txt.php?id=BOE-A2010-12269 (Consult January 2021)

[5] LOPEZ A.G., (2012), "Pensamiento crítico en el aula" in Docencia e Investigación, Número 22, pp. 41-60, https://www.educacion.to.uclm.es/pdf/revistaDI/3_22_2012.pdf (Consult January 2021)

[6] NORMAN-ACEVEDO, E., DAZA-OROZCO, C.E. (2020). "Construcción de contenidos para la enseñanza virtual: retos coyunturales en el confinamiento" in Revista Panorama, vol. 14, no. 27, p. 1-8. https://journal.poligran.edu.co/index.php/panorama/article/view/1517 (Consult January 2021)

[7] SCHNABEL, M. A. (2002) "Collaborative studio in a virtual environment" in International Conference on Computers in Education Proceedings., Auckland, New Zealand, p. 337-341 . https://www.researchgate.net/publication/4007124_Collaborative_studio_in_a_virtual_environm ent (Consult January 2021)

[8] VAN DE HEYDE, V., SIEBRITS, A. (2019). "The ecosystem of e-learning model for higher education" in South African Journal of Science, vol. 115, no. 5-6, p. 1-6. https://www.sajs.co.za/article/view/5808 (Consult January 2021)

[9] VEGAS F. et al. (2018) "Architects for the future': updating and transferring content through new learning experiences" in 2th International Technology, Education and Development Conference Valencia, Spain. 5-7 March, 2018, lated ed., p.5937-5942

https://library.iated.org/view/VEGASLOPEZMANZANARES2018ARC (Consult January 2021) 